\title{
Currently Available Antiepileptic Drugs
}

\author{
Steven C. Schachter \\ Harvard Medical School, Boston, Massachusetts 02215
}

Summary: Many new antiepileptic drugs (AEDs) have become available over the past 15 years. At the same time, the emphasis on treating patients with epilepsy has grown from stopping seizures to avoiding side effects and maximizing quality of life. This review summarizes currently available AEDs, and presents general treatment principles and guidelines for
AED selection. Unfortunately, despite the increased treatment options of today, seizure freedom without side effects remains unattainable for too many patients with epilepsy. Consequently, there remains a significant need for further development of new therapies. Key Words: Epilepsy, seizure, antiepileptic drug, refractory, side effects.

\section{INTRODUCTION}

Over the last 15 years, a new generation of antiepileptic drugs (AEDs) has emerged for the pharmacological management of seizures. Concurrent with that development, the concept of optimum therapy for seizures has evolved to include complete control of seizures, absence of bothersome side effects, and an emphasis on maximizing quality of life. ${ }^{1,2}$ With the AEDs now available and access to physicians familiar with their use, patients with epilepsy have a greater chance to achieve these treatment goals than in the past. ${ }^{3}$ Nonetheless, the prospect of freedom from seizures and side effects remains elusive for a considerable number of patients with epilepsy despite concerted attempts by their physicians to utilize available pharmacotherapies to their full advantage.

This review provides an overview of the currently available AEDs that are widely used in the U.S. for the chronic treatment of epilepsy, and discusses general treatment principles, guidelines for AED selection, and treatment outcomes. Determining when to initiate and terminate treatment, assessing compliance, considering the special requirements of defined populations such as children and pregnant women, and evaluating and addressing psychosocial problems associated with epilepsy are important topics related to effective AED therapy,

Address for correspondence and reprint requests to: Steven C. Schachter, M.D., Beth Israel Deaconess Medical Center, KS-478, 330 Brookline Avenue, Boston, MA 02215. E-mail: sschacht@bidmc. harvard.edu. but are beyond the scope of this review and thoroughly covered elsewhere. ${ }^{4-6}$

\section{GENERAL TREATMENT PRINCIPLES FOR THE CURRENT AEDS}

The effectiveness of the newer AEDs was determined with regulatory trials and postmarketing studies in patients with defined seizure types. Therefore, the first step in selecting among the currently available AEDs for a particular patient is to determine his or her seizure type(s). Concomitant medical conditions and medications, lifestyle, and other factors also contribute to the decision regarding choice of drug treatment. Once chosen, the AED is generally started at a low dosage and slowly titrated to the maximum-tolerated dose. If the first AED is unsuccessful because of ineffectiveness or side effects, then a second AED, also appropriate for the target seizure type(s), is generally prescribed. The second AED should be titrated to a tolerable and effective dosage before the first AED is tapered. In general, it is preferable to maintain a patient on a single AED rather than combinations of AEDs because compliance is enhanced, overall medication costs are usually less, and there are generally fewer idiosyncratic reactions, teratogenic effects, and side effects (though not invariably). ${ }^{7}$ Nonetheless, some patients do better on combinations of AEDs than on individual agents.

Effective management using currently available AEDs requires detailed knowledge of their pharmacodynamic and pharmacokinetic profiles, which vary significantly as shown in Tables 1 and 2. Side effects are a major cause 
TABLE 1. Common and Rare Side Effects of Available Antiepileptic Drugs

\begin{tabular}{|c|c|c|c|c|}
\hline Drug & $\begin{array}{l}\text { U.S. Trade } \\
\text { Name }\end{array}$ & Systemic Side Effects & Neurotoxic Side Effects & Rare Idiosyncratic Reactions \\
\hline Carbamazepine & $\begin{array}{l}\text { Tegretol, } \\
\text { Carbatrol }\end{array}$ & $\begin{array}{l}\text { Nausea, vomiting, diarrhea, } \\
\text { hyponatremia, rash, } \\
\text { pruritus, fluid retention }\end{array}$ & $\begin{array}{l}\text { Drowsiness, dizziness, } \\
\text { blurred or double } \\
\text { vision, lethargy, } \\
\text { headache }\end{array}$ & $\begin{array}{l}\text { Agranulocytosis, Stevens-Johnson } \\
\text { syndrome, aplastic anemia, } \\
\text { hepatic failure, dermatitis-rash, } \\
\text { serum sickness, pancreatitis }\end{array}$ \\
\hline Ethosuximide & Zarontin & Nausea, vomiting & $\begin{array}{l}\text { Sleep disturbance, } \\
\text { drowsiness, } \\
\text { hyperactivity }\end{array}$ & $\begin{array}{l}\text { Agranulocytosis, Stevens-Johnson } \\
\text { syndrome, aplastic anemia, } \\
\text { dermatitis-rash, serum sickness }\end{array}$ \\
\hline Felbamate & Felbatol & $\begin{array}{l}\text { Nausea, vomiting, } \\
\text { anorexia, weight loss }\end{array}$ & $\begin{array}{l}\text { Insomnia, dizziness, } \\
\text { headache, ataxia }\end{array}$ & Aplastic anemia, hepatic failure \\
\hline Gabapentin & Neurontin & None known & $\begin{array}{l}\text { Somnolence, dizziness, } \\
\text { ataxia }\end{array}$ & Unknown \\
\hline Phenytoin & $\begin{array}{l}\text { Dilantin, } \\
\text { Phenytek }\end{array}$ & $\begin{array}{l}\text { Gingival hypertrophy, body } \\
\text { hair increase, rash, } \\
\text { lymphadenopathy }\end{array}$ & $\begin{array}{l}\text { Confusion, slurred } \\
\text { speech, double } \\
\text { vision, ataxia, } \\
\text { neuropathy (with } \\
\text { long-term use) }\end{array}$ & $\begin{array}{l}\text { Agranulocytosis, Stevens-Johnson } \\
\text { syndrome, aplastic anemia, } \\
\text { hepatic failure, dermatitis-rash, } \\
\text { serum sickness }\end{array}$ \\
\hline Lamotrigine & Lamictal & Rash, nausea & Dizziness, somnolence & $\begin{array}{l}\text { Stevens-Johnson syndrome, } \\
\text { hypersensitivity syndrome }\end{array}$ \\
\hline Levetiracetam & Keppra & Anorexia & $\begin{array}{l}\text { Somnolence, dizziness, } \\
\text { headache, } \\
\text { nervousness }\end{array}$ & $\mathrm{N} / \mathrm{A}$ \\
\hline Oxcarbazepine & Trileptal & $\begin{array}{l}\text { Nausea, vomiting, } \\
\text { hyponatremia, rash }\end{array}$ & $\begin{array}{l}\text { Drowsiness, dizziness, } \\
\text { headache, double } \\
\text { vision, ataxia }\end{array}$ & $\begin{array}{l}\text { Dermatitis-rash, Stevens-Johnson } \\
\text { syndrome, toxic epidermal } \\
\text { necrolysis }\end{array}$ \\
\hline Pregabalin & Lyrica & $\begin{array}{l}\text { Weight gain, peripheral } \\
\text { edema }\end{array}$ & $\begin{array}{l}\text { Dizziness, somnolence, } \\
\text { asthenia, headache, } \\
\text { ataxia }\end{array}$ & N/A \\
\hline $\begin{array}{l}\text { Primidone, } \\
\text { Phenobarbital }\end{array}$ & Mysoline & Nausea, rash & $\begin{array}{l}\text { Alteration of sleep } \\
\text { cycles, sedation, } \\
\text { lethargy, behavioral } \\
\text { changes, } \\
\text { hyperactivity, ataxia, } \\
\text { dependence }\end{array}$ & $\begin{array}{l}\text { Agranulocytosis, Stevens-Johnson } \\
\text { syndrome, hepatic failure, } \\
\text { dermatitis-rash, serum sickness }\end{array}$ \\
\hline Tiagabine & Gabitril & N/A & $\begin{array}{l}\text { Dizziness, weakness, } \\
\text { ataxia nervousness, } \\
\text { tremor, somnolence }\end{array}$ & N/A \\
\hline Topiramate & Topamax & Anorexia, weight loss & $\begin{array}{l}\text { Confusion, cognitive } \\
\text { slowing, dysphasia, } \\
\text { dizziness, fatigue, } \\
\text { paresthesias }\end{array}$ & $\begin{array}{l}\text { Nephrolithiasis, hypohidrosis, } \\
\text { acute angle closure glaucoma }\end{array}$ \\
\hline Valproate & Depakote & $\begin{array}{l}\text { Weight gain, nausea, } \\
\text { vomiting, hair loss, easy } \\
\text { bruising }\end{array}$ & Tremor & $\begin{array}{l}\text { Agranulocytosis, Stevens-Johnson } \\
\text { syndrome, aplastic anemia, } \\
\text { hepatic failure, dermatitis-rash, } \\
\text { serum sickness, pancreatitis }\end{array}$ \\
\hline Zonisamide & Zonegran & Anorexia & $\begin{array}{l}\text { Dizziness, ataxia, } \\
\text { fatigue, somnolence, } \\
\text { confusion }\end{array}$ & $\begin{array}{l}\text { Nephrolithiasis, oligohydrosis and } \\
\text { hyperthermia }\end{array}$ \\
\hline
\end{tabular}

of medication intolerance and noncompliance, particularly within the first six months of therapy. Neurotoxic effects of commonly used AEDs (TABLE 1) are generally dose-related and often dose-limiting. Patients who have peak-level side effects may benefit from a modification of the treatment schedule, such as spreading out the dosage or giving proportionally more at bedtime. Notably, serum concentrations that are associated with neurotoxicity vary from one patient to another with current AEDs, and may occur within the so-called "thera- peutic range." Table 2 shows the variability of pharmacokinetic profiles of current AEDs, including dosing schedule, number of days needed to achieve steady state, and frequency of initial laboratory monitoring.

\section{OLDER GENERATION AEDS}

\section{Carbamazepine}

Carbamazepine (CBZ) blocks voltage-dependent sodium channels, thereby limiting rapid, repetitive neuro- 
TABLE 2. Pharmacokinetic Properties of Available Antiepileptic Drugs

\begin{tabular}{|c|c|c|c|c|c|c|}
\hline Drug & $\begin{array}{l}\text { Percent Bound } \\
\text { to Plasma } \\
\text { Protein }\end{array}$ & $\begin{array}{l}\text { Elimination Half- } \\
\text { life }(\mathrm{h})\end{array}$ & $\begin{array}{l}\text { Time to } \\
\text { Steady State } \\
\text { (days) }\end{array}$ & $\begin{array}{l}\text { Frequency of } \\
\text { Dosing }\end{array}$ & $\begin{array}{c}\text { Frequency of Initial } \\
\text { Monitoring }\end{array}$ & $\begin{array}{l}\text { Therapeutic } \\
\text { Level (ug/ml) }\end{array}$ \\
\hline Carbamazepine & $70-80$ & $\begin{array}{l}\text { 11-17 (chronic } \\
\text { therapy) }\end{array}$ & $3-10$ & $\begin{array}{l}\text { bid, tid, or } \\
\text { qid }\end{array}$ & $3,6,9$ weeks & $4-12$ \\
\hline Ethosuximide & 0 & $40-50$ & $6-12$ & qd, bid, or tid & 2-3 weeks & $40-100$ \\
\hline Felbamate & 25 & $20-23$ & $5-10$ & bid or tid & $\begin{array}{l}\text { See package insert } \\
\text { for detailed } \\
\text { instructions }\end{array}$ & $32-137$ \\
\hline Gabapentin & 0 & $\begin{array}{l}\text { 5-7; increases with } \\
\text { decreased } \\
\text { creatinine } \\
\text { clearance (see } \\
\text { prescribing } \\
\text { information) }\end{array}$ & $1-2$ & tid & none & $2-3$ \\
\hline Lamotrigine & $50-55$ & $\begin{array}{l}\text { 10-15 with } \\
\text { enzyme-inducing } \\
\text { AEDs*; 40-60 } \\
\text { with VPA }\end{array}$ & $5-15$ & bid & None & $\begin{array}{l}\text { Not } \\
\quad \text { established }\end{array}$ \\
\hline Levetiracetam & $<10$ & $7-8$ & $3-4$ & bid & None & $\begin{array}{l}\text { Not } \\
\text { established }\end{array}$ \\
\hline Oxcarbazepine & 40 & $8-10$ & $3-4$ & bid, tid & $\begin{array}{l}\text { None (except } \\
\text { sodium every 2-4 } \\
\text { weeks in patients } \\
\text { at risk for } \\
\text { hyponatremia) }\end{array}$ & $\begin{array}{l}\text { Not } \\
\quad \text { established }\end{array}$ \\
\hline Phenobarbital & $40-60$ & $30-50$ & $16-21$ & qd or bid & 3-4 weeks & $10-40$ \\
\hline Phenytoin & 90 & $15-30$ & $5-15$ & qd or bid & 2-3 weeks & $10-20$ \\
\hline Pregabalin & 0 & 6 & 2 & bid, tid & None & $\begin{array}{l}\text { Not } \\
\text { established }\end{array}$ \\
\hline Tiagabine & 96 & $5-9$ & 3 & bid, tid, qid & None & $\begin{array}{l}\text { Not } \\
\quad \text { established }\end{array}$ \\
\hline Topiramate & $9-17$ & $20-24$ & $5-7$ & bid & none & $\begin{array}{l}\text { Not } \\
\text { established }\end{array}$ \\
\hline Valproate & $\begin{array}{l}\text { 60-95 (decreases } \\
\text { with serum } \\
\text { levels over } \\
100 \mathrm{ug} / \mathrm{ml})\end{array}$ & $6-18$ & $2-4$ & bid or tid & 1-2 weeks & $50-150$ \\
\hline Zonisamide & $40-60$ & $50-68$ & $12-14$ & qd, bid & none & $\begin{array}{l}\text { Not } \\
\quad \text { established }\end{array}$ \\
\hline
\end{tabular}

AEDs = antiepileptic drugs. Bid (bis in die) = twice a day; tid (ter in die) = three times daily; qd = each day; qid = four times daily.

* Such as carbamazepine, phenytoin, and phenobarbital

nal firing. Other mechanisms may be relevant to its anticonvulsant effect as well. Carbamazepine is a first-line treatment for partial-onset and primary generalized tonic-clonic seizures, but is ineffective against, and may exacerbate, absence and myoclonic seizures. ${ }^{8}$ To minimize CNS-related side effects, CBZ should be initiated at $100-200 \mathrm{mg}$ daily and increased by $100-200 \mathrm{mg}$ increments every 3-14 days as needed for seizure control, typically over one to two months. The final dose in part depends on the extent of autoinduction; i.e., the degree to which CBZ induces its own metabolism. Diplopia, headache, dizziness, nausea, and vomiting are the most common dose-related side effects, which typically occur two to three hours after a dose. Use of a controlled-release formulation can reduce the severity of side effects. Car- bamazepine is also associated with idiosyncratic side effects, including a morbilliform rash in around $10 \%$ of patients, and more rarely, serious rashes such as StevensJohnson syndrome. ${ }^{9}$ Reversible mild leucopenia may occur within the first two to three months, but usually does not necessitate discontinuation of therapy. Potentially fatal hematologic and hepatic effects are very rare. An antidiuretic hormone-like action leading to hyponatremia is infrequent and usually asymptomatic. ${ }^{10}$ Carbamazepine is teratogenic, and has been associated with spina bifida in some ${ }^{11,12}$ but not all ${ }^{13}$ studies.

Hepatic metabolism is induced by CBZ; therefore, clearance of many AEDs and non-AEDs, ${ }^{14}$ including hormonal contraceptives, ${ }^{15}$ is increased when coadministered with CBZ. Likewise, drugs that inhibit CBZ me- 
tabolism, such as cimetidine, dextropropoxyphene, diltiazem, erythromycin, isoniazid, verapamil, viloxazine, and fluoxetine, may precipitate CBZ-related side effects.

\section{Ethosuximide}

Ethosuximide (ESM) reduces T-type calcium currents in thalamic neurons. ${ }^{16}$ It is a first-line treatment for patients with absence seizures ${ }^{7}$ but ineffective against myoclonic, primary generalized tonic-clonic, and partial-onset seizures. The usual initial dose is $\mathbf{2 5 0 - 5 0 0 ~ m g ~ d a i l y , ~}$ with $250 \mathrm{mg}$ dose increments over two to three weeks as needed for seizure control. Side effects include hiccups, nausea, vomiting, abdominal pain, anorexia, headache, dizziness, drowsiness, and unsteadiness. Allergic rashes occur in approximately $5 \%$ of patients, and drug interactions are not a significant problem.

\section{Phenobarbital}

Phenobarbital (PB) augments the inhibitory effect of GABA by prolonging the chloride-channel opening at the $\mathrm{GABA}_{\mathrm{A}}$ receptor. Phenobarbital is effective against partial-onset seizures, primary generalized tonic-clonic seizures, and myoclonic seizures but is widely considered a second-line drug because of behavioral and cognitive effects, ${ }^{18}$ including sedation, depression, agitation, and hyperactivity in children and the elderly. Intravenous PB is useful for the treatment of status epilepticus. ${ }^{19}$ Daily maintenance dosages in adults range from 60-240 $\mathrm{mg}(2-5 \mathrm{mg} / \mathrm{kg} / \mathrm{day}$ in children). Because the half-life of $\mathrm{PB}$ is four days, steady-state serum concentrations are not reached until approximately three weeks after a dosage change. Abrupt discontinuation can precipitate withdrawal seizures. ${ }^{20}$ Phenobarbital is associated with a significantly increased risk of fetal abnormalities. ${ }^{21}$ Hepatic metabolism is induced by PB, and the clearance of concomitantly administered hepatically metabolized drugs, including hormonal contraceptives, ${ }^{15}$ is increased.

\section{Phenytoin}

Phenytoin (PHT) blocks voltage-dependent neuronal sodium channels and is a first-line treatment for partialonset and primary generalized tonic-clonic seizures. Phenytoin is ineffective against myoclonic, atonic, and absence seizures. Intravenous PHT and fosphenytoin, a PHT prodrug, are useful for quickly providing a loading dose and for treating status epilepticus. ${ }^{22,23}$ In a nonurgent situation, oral treatment is often started at the anticipated maintenance dose, typically $300 \mathrm{mg} / \mathrm{day}$ administered either as a single dose or in two divided doses in adults $(5-8 \mathrm{mg} / \mathrm{kg} /$ day in children). Neurotoxic side effects include ataxia, nystagmus, dysarthria, asterixis, and somnolence. Long-term use has been associated with gingival hyperplasia, hirsutism, acne, facial coarsening, and, less commonly, folate deficiency, osteopenia, peripheral neuropathy, and cerebellar atrophy. A diffuse allergic rash occurs in 5-10\% of patients. Other idiosyn- cratic reactions are rare, and include Stevens-Johnson syndrome, hepatitis, bone marrow suppression, lymphadenopathy, and a lupus-like syndrome. Phenytoin is teratogenic. $^{24}$

The hepatic metabolism of PHT becomes saturated at moderate-to-high serum concentrations in an age-dependent fashion, which results in nonlinear pharmacokinetics. ${ }^{25}$ Phenytoin induces hepatic enzymes, reducing serum concentrations of other hepatically metabolized AEDs such as CBZ, valproate (VPA), lamotrigine (LTG), and topiramate (TPM), as well as hormonal contraceptives. ${ }^{15}$ Phenytoin is tightly bound to circulating albumin and may be displaced by other protein-bound drugs such as VPA.

\section{Primidone}

Primidone (PRM) is metabolized in the liver to PB and another active compound, phenylethylmalonamide. ${ }^{26}$ Primidone is effective against partial-onset and primary generalized tonic-clonic seizures, but is considered second line because of dose-related neurotoxicity, the effects of which include sedation, ataxia, and diminished libido. Dosing is usually initiated with $125 \mathrm{mg}$ at bedtime, and increased by $125 \mathrm{mg}$ every three to five days as needed for seizure control up to $1500 \mathrm{mg}$ daily. As with $\mathrm{PB}$, abrupt discontinuation of PRM should be avoided. ${ }^{20}$ Primidone induces hepatic metabolism and is therefore prone to the same drug-drug interactions as $\mathrm{PB}$.

\section{Sodium valproate}

Sodium valproate (VPA) blocks voltage-dependent sodium channels, facilitates the effects of the inhibitory neurotransmitter GABA, and reduces low threshold (Ttype) calcium currents. ${ }^{16}$ Sodium valproate is effective for virtually all seizure types. ${ }^{27}$ Therapy is initiated with $500 \mathrm{mg}$ once or twice daily, and titrated as needed for seizure control. An intravenous form allows for a loading dose and substitution for oral therapy when needed. ${ }^{28,29}$ Side effects include dose-related tremor, weight gain, and hair thinning. Though controversial, evidence suggests that VPA promotes the development of menstrual irregularities and other endocrinologic features of the polycystic ovarian syndrome. ${ }^{30-32}$ Thrombocytopenia and pancreatitis occur rarely, and very young children on combinations of VPA and other AEDs may develop significant hepatotoxicity. Sodium valproate is teratogenic, ${ }^{12}$ and has been associated with neural tube defects. ${ }^{33}$ Sodium valproate inhibits hepatic metabolism, reducing the clearance of PHT, PB, CBZ-epoxide, and LTG.

\section{NEWER GENERATION AEDS}

\section{Felbamate}

Felbamate (FBM) potentiates GABA-mediated inhibition, and blocks voltage-dependent sodium channels as well as the ionic channel at the $\mathrm{N}$-methyl-d-aspartate 
receptor. ${ }^{34}$ Felbamate is effective against partial-onset seizures as well as generalized seizures (including atonic seizures) associated with the Lennox-Gastaut syndrome in children. ${ }^{35}$ Dosing is titrated slowly over several weeks to minimize side effects. Side effects include insomnia, headache, nausea, anorexia, somnolence, vomiting, weight loss, and dizziness. ${ }^{36}$ There is an elevated risk of aplastic anemia and fatal hepatitis, ${ }^{37}$ which has dramatically curtailed the use of FBM. Routine monitoring of liver and blood counts is recommended, but does not predict potentially fatal toxicity. Consequently, FBM is now primarily used in patients with Lennox-Gastaut syndrome where the benefits of treatment outweigh the risks. Felbamate is metabolized by the liver and reduces the clearance of PHT, VPA, and CBZ-epoxide, as well as hormonal contraceptives. ${ }^{15}$

\section{Gabapentin}

Gabapentin (GBP) binds to the $\alpha 2 \delta$ subunit of neuronal voltage-gated calcium channels, inhibiting calcium flow. Gabapentin is effective against partial-onset seizures but may exacerbate myoclonic and absence seizures. The typical initial dose is $300 \mathrm{mg}$ daily, which is increased by $300 \mathrm{mg}$ every three days, as needed for seizure control, to the maximum tolerated dose. Side effects include drowsiness, ataxia, dizziness, weight gain, and peripheral edema. Gabapentin is not metabolized and has no effect on hepatic metabolism; consequently, there are no significant drug interactions. Because GBP is eliminated by the kidneys, patients with renal insufficiency require lower dosages and less frequent dosing. A risk profile to exposed fetuses has not been established.

\section{Lamotrigine}

Lamotrigine is a sodium channel blocker that is effective against partial-onset seizures and generalized seizure subtypes, though it has been reported to exacerbate myoclonic seizures, ${ }^{38}$ especially in patients with severe myoclonic epilepsy. ${ }^{39}$ Dosing is started at a low dose, $25-50$ $\mathrm{mg}$ daily, and increased slowly to reduce the likelihood of rash. Starting dosages, subsequent increments, and target maintenance dosages are reduced in patients comedicated with VPA. ${ }^{40,41}$ Side effects include rash, headache, nausea, insomnia, vomiting, dizziness, diplopia, ataxia, and tremor. Neurotoxic side effects of LTG are accentuated when LTG is taken simultaneously with CBZ. Severe skin reactions, including bullous erythema multiforme, Stevens-Johnson syndrome, and toxic epidermal necrolysis occur in up to 1 in 1000 adults and 1 in 100 children; the risk is reduced with slow and gradual titration $^{42}$ as recommended in the package insert. Recent data from a pregnancy registry suggest an increased risk of isolated cleft lip or palate. The half-life of LTG is reduced during pregnancy ${ }^{43}$ and by enzyme-inducing drugs, and significantly increased by VPA, which inhibits the glucuronidation of LTG.

\section{Levetiracetam}

Levetiracetam (LEV) binds to synaptic vesicle protein and has actions on neuronal GABA- and glycine-gated currents, as well as voltage-dependent potassium currents, though its exact mechanism of action is unknown. Levetiracetam is effective against partial-onset seizures ${ }^{44}$ as well as generalized seizure types, including myoclonic and absence seizures. Dosing is initiated at $500-1000 \mathrm{mg}$ daily and titrated at $1000 \mathrm{mg}$ increments every two weeks as tolerated and needed for seizure control. Common side effects are somnolence, headache, anorexia, and nervousness. ${ }^{45}$ Less frequently, patients or families may report agitation, aggression, anxiety, or depression. Teratogenicity has not been established. There are no pharmacokinetic interactions with other drugs, including oral contraceptives. ${ }^{46-48}$ Clearance is reduced in patients with renal insufficiency.

\section{Oxcarbazepine}

Oxcarbazepine (OXC) is the prodrug for its active metabolite, 10,11-dihydro-10-hydroxycarbazapine, which blocks voltage-dependent sodium channels, and modulates calcium and potassium currents. Oxcarbazepine is the 10,11 keto analogue of CBZ, and has a similar spectrum of efficacy against partial-onset ${ }^{44}$ and primary generalized tonic-clonic seizures. Dosage is usually initiated at $150-600 \mathrm{mg}$ daily in adults and titrated every one to two weeks as needed to control seizures and as tolerated. Common side effects are drowsiness, dizziness, headache, diplopia, nausea, vomiting, and ataxia. ${ }^{49} \mathrm{An}$ allergic rash is infrequent and instances of Stevens-Johnson syndrome and toxic epidermal necrolysis are rare. ${ }^{50}$ Hyponatremia, which is usually asymptomatic, occurs more commonly than with CBZ. ${ }^{3}$ The teratogenic risk has not been determined. Oxcarbazepine induces the metabolism of hormonal contraceptives ${ }^{15}$ and may increase PHT serum concentrations through inhibition of the cytochrome P-450 isoenzyme 2C19.

\section{Pregabalin}

Pregabalin (PGB) binds with high affinity to the $\alpha 2 \delta$ subunit of neuronal voltage-gated calcium channels and inhibits calcium flow, an action similar to GBP. ${ }^{51}$ Pregabalin is effective against partial-onset seizures and is six to eight times more potent than GBP. ${ }^{52}$ The usual initial dose is $150 \mathrm{mg}$ daily, with subsequent titration every five to seven days to an effective and tolerable maintenance dose. Side effects include dizziness, somnolence, asthenia, headache, ataxia, weight gain, and peripheral edema. Teratogenicity has not been fully evaluated. Pregabalin has no pharmacokinetic interactions with other drugs and is excreted by the kidneys. Conse- 
quently, dosage reduction and less frequent dosing are recommended for patients with renal insufficiency.

\section{Tiagabine}

Tiagabine (TGB) inhibits neuronal and glial reuptake of GABA, which increases the availability of GABA to inhibit postsynaptic neurons. ${ }^{53}$ Tiagabine is effective against partial-onset seizures, but has been reported to rarely precipitate absence stupor. ${ }^{54}$ Treatment is initiated with $4-8 \mathrm{mg}$ daily, and increased weekly by $4-8 \mathrm{mg}$ as needed for control of seizures and as tolerated. ${ }^{55}$ Side effects include dizziness, asthenia, muscle weakness, nervousness, tremor, impaired concentration, lethargy, and depression, ${ }^{56}$ which may be lessened by taking TGB with food. The risk of teratogenicity has not been established. Tiagabine is hepatically metabolized, and its clearance is increased when TGB is coadministered with hepatic enzyme-inducing AEDs. Doses should be reduced in patients with significant hepatic impairment. ${ }^{57}$

\section{Topiramate}

Topiramate blocks sodium channels and high voltageactivated calcium channels, attenuates the effects of excitatory neurotransmitters, enhances GABAergic neurotransmission, and inhibits carbonic anhydrase, though the relevance of this last mechanism to its anticonvulsant effect is uncertain. Topiramate is used for partial-onset, primary generalized tonic-clonic and myoclonic seizures. The initial dose is $25-50 \mathrm{mg}$ daily, which is increased by $25-50 \mathrm{mg}$ every one to two weeks as needed for seizure control. Side effects include word-finding disturbance, cognitive slowing, ataxia, poor concentration, dizziness, fatigue, paresthesia, somnolence, reduced appetite, and weight loss. ${ }^{58,59}$ In addition, there is a small increased risk of kidney stone formation, hypohydrosis, ${ }^{60}$ and acute angle closure glaucoma. ${ }^{3}$ Effects on exposed fetuses have not been determined. Topiramate increases the metabolism of hormonal contraceptives ${ }^{15}$ and infrequently inhibits the metabolism of PHT. The clearance of TPM is increased by CBZ and PHT. ${ }^{61}$

\section{Zonisamide}

Zonisamide (ZNS) blocks voltage-dependent sodium channels as well as T-type calcium channels, and inhibits carbonic anhydrase. Zonisamide is effective against partial-onset seizures and generalized seizure subtypes, tonic-clonic, tonic, atonic, atypical absence, and myoclonic seizures. ${ }^{44,62}$ The recommended initial dose is $100 \mathrm{mg}$ daily for adult patients and $2 \mathrm{mg} / \mathrm{kg} /$ day for children in two divided dosages. Because steady state is reached slowly, doses should be increased at two-week intervals to the target maintenance dose. Side effects include anorexia, dizziness, ataxia, fatigue, somnolence, confusion, and poor concentration. Less than 5\% of patients develop renal stones. ${ }^{63}$ Oligohydrosis and hyperthermia have been rarely reported in children. ${ }^{64}$ The risk of teratoge- nicity has not been determined. Zonisamide has no effect on hepatic metabolism, but its half-life is reduced by enzyme-inducing AEDs. ${ }^{65}$ Patients with renal dysfunction have reduced clearance.

\section{AED SELECTION: GUIDELINES AND EXPERT OPINION}

The treatment of epilepsy has become increasingly complex with the introduction of new AEDs, new formulations of older AEDs, and the vagus nerve stimulator. Ideally, the selection of therapy should be based on experimental evidence. Recently published AED treatment guidelines from the American Academy of Neurology and the American Epilepsy Society for the use of GBP, LTG, TPM, TGB, OXC, LEV, and ZNS in the treatment of new-onset and medically refractory seizures are based on evidence of efficacy, tolerability, and safety in adults and children. ${ }^{66,67}$ However, while clinical practice is ideally evidence-based, there are clinical situations requiring AED selections for which there are few if any relevant clinical studies. ${ }^{68}$ For example, there are few head-to-head studies of currently available AEDs as initial therapy for specific seizure types or age groups. In such circumstances, where data is incomplete or unavailable, expert opinion can provide some direction to the clinician. A technique for assessing expert opinion based on the Rand method has been applied to determining consensus among a group of epilepsy experts with regard to selection of AEDs for particular clinical situations. The most recent expert consensus was based on data survey results obtained in 2004 from 48 American epilepsy specialists covering all of the newer AEDs excepting pregabalin. The methodology, inherent limitations, and complete findings are described in the full report. ${ }^{69}$

\section{OUTLOOK FOR THERAPEUTIC SUCCESS WITH CURRENT AEDS}

A long-term observational study of previously untreated adolescent and adult patients with newly diagnosed epilepsy, published in 2000 (before all the newer AEDs were marketed), indicated that nearly $50 \%$ of patients became seizure free with the initial AED. ${ }^{70}$ Among the remaining patients, approximately one in three patients became seizure free with additional treatment. Therefore, a significant proportion of patients under the care of epilepsy experts did not achieve full seizure control with available AEDs. The question of whether the situation is substantially different today requires a randomized, controlled trial to fully determine an answer, but significant difference appears unlikely, given the findings of another study ${ }^{71}$ that showed fewer than $25 \%$ of patients with medically refractory epilepsy who 
were then started on LTG, GBP, and TPM were expected to continue on those agents for more than five years.

Current AEDs suppress seizures, but there is no evidence that any are antiepileptogenic; i.e., capable of preventing the onset of seizures in patients at high risk or inducing a permanent remission of seizures in patients with epilepsy. ${ }^{72-75}$

\section{CONCLUSIONS}

In a majority of patients with epilepsy, an accurate diagnosis of seizure type and the appropriate selection and utilization of currently available AEDs will lead to therapeutic success. However, there is no current treatment that is proven to prevent the onset or progressive course of epilepsy; many patients with epilepsy will continue to have seizures and/or distressing side effects, and current AEDs are often problematic to use by patients and to manage by physicians. Fortunately, new chemical entities and derivatives of current AEDs are in development, ${ }^{76,77}$ and with further understanding of the mechanisms underlying pharmacoresistance, systemic effects, neurotoxicity, and epileptogenesis, ${ }^{78}$ effective, completely safe, easy to use, and tolerable AEDs, as well as potentially antiepileptogenic therapies, may eventually become widely available. ${ }^{17}$

\section{REFERENCES}

1. Schachter SC. Quality of life for patients with epilepsy is determined by more than seizure control: the role of psychosocial factors. Expert Rev Neurother 2006;6:111-118.

2. Schachter SC. Improving quality of life beyond seizure control. Epileptic Disord 2005;7(suppl 1):34-38.

3. Asconape JJ. Some common issues in the use of antiepileptic drugs. Semin Neurol 2002;22:27-39.

4. Brodie MJ, Schachter SC, Kwan P. Epilepsy. 3rd ed. Oxford, England: Health Press; 2005.

5. Levy RH, Mattson RH, Meldrum BS, Perucca E, Antiepileptic drugs. 5th ed. Philadelphia: Lippincott Williams \& Wilkins; 2002.

6. Wyllie E, Gupta A, Lachhwani DK, eds. The treatment of epilepsy. Philadelphia: Lippincott Williams \& Wilkins; 2006.

7. Deckers CL, Hekster YA, Keyser A, van Lier HJ, Meinardi H, Renier WO. Monotherapy versus polytherapy for epilepsy: a multicenter double-blind randomized study. Epilepsia 2001;42:13871394.

8. Genton P, Gelisse P, Thomas P, Dravet C. Do carbamazepine and phenytoin aggravate juvenile myoclonic epilepsy? Neurology 2000;55:1106-1109.

9. Mockenhaupt M, Messenheimer J, Tennis P, Schlingmann J. Risk of Stevens-Johnson syndrome and toxic epidermal necrolysis in new users of antiepileptics. Neurology 2005;64:1134-1138.

10. Isojarvi JI, Huuskonen UE, Pakarinen AJ, Vuolteenaho O, Myllyla VV. The regulation of serum sodium after replacing carbamazepine with oxcarbazepine. Epilepsia 2001;42:741-745.

11. Yerby MS. Management issues for women with epilepsy: neural tube defects and folic acid supplementation. Neurology 2003;61: S23-S26.

12. Kaaja E, Kaaja R, Hiilesmaa V. Major malformations in offspring of women with epilepsy. Neurology 2003;60:575-579.

13. Artama M, Auvinen A, Raudaskoski T, Isojarvi I, Isojarvi J. Antiepileptic drug use of women with epilepsy and congenital malformations in offspring. Neurology 2005;64:1874-1878.
14. Spina E, Perucca E. Clinical significance of pharmacokinetic interactions between antiepileptic and psychotropic drugs. Epilepsia 2002;43:37-44.

15. Crawford P. Interactions between antiepileptic drugs and hormonal contraception. CNS Drugs 2002;16:263-272.

16. Macdonald RL, Kelly KM. Antiepileptic drug mechanisms of action. Epilepsia 1995;36(suppl 2):S2-S12.

17. Sato S, White BG, Penry JK, Dreifuss FE, Sackellares JC, Kupferberg HJ. Valproic acid versus ethosuximide in the treatment of absence seizures. Neurology 1982;32:157-163.

18. Meador KJ. Cognitive outcomes and predictive factors in epilepsy. Neurology 2002;58:S21-S26.

19. Mattson RH. Parenteral antiepileptic/anticonvulsant drugs. Neurology 1996;46:S8-S13.

20. Theodore WH, Porter RJ, Raubertas RF. Seizures during barbiturate withdrawal: relation to blood level. Ann Neurol 1987;22:644647.

21. Holmes LB, Wyszynski DF, Lieberman E. The AED (antiepileptic drug) pregnancy registry: a 6-year experience. Arch Neurol 2004; 61:673-678.

22. Willmore LJ. Epilepsy emergencies: the first seizure and status epilepticus. Neurology 1998;51:S34-S38.

23. Browne TR, Kugler AR, Eldon MA. Pharmacology and pharmacokinetics of fosphenytoin. Neurology 1996;46:S3-S7.

24. Kaneko S, Battino D, Andermann E, et al. Congenital malformations due to antiepileptic drugs. Epilepsy Res 1999;33:145-158.

25. Birnbaum A, Hardie NA, Leppik IE, et al. Variability of total phenytoin serum concentrations within elderly nursing home residents. Neurology 2003;60:555-559.

26. Baumel IP, Gallagher BB, Mattson RH. Phenylethylmalonamide (PEMA). An important metabolite of primidone. Arch Neurol 1972;27:34-41.

27. Perucca E. Pharmacological and therapeutic properties of valproate: a summary after 35 years of clinical experience. CNS Drugs 2002;16:695-714.

28. Venkataraman V, Wheless JW. Safety of rapid intravenous infusion of valproate loading doses in epilepsy patients. Epilepsy Res 1999;35:147-153.

29. Wheless J, Venkataraman V. Safety of high intravenous valproate loading doses in epilepsy patients. J Epilepsy 1998;11:319-324.

30. Morrell MJ. Reproductive and metabolic disorders in women with epilepsy. Epilepsia 2003;44:11-20.

31. Isojarvi JI, Tauboll E, Tapanainen JS, et al. On the association between valproate and polycystic ovary syndrome: a response and an alternative view. Epilepsia 2001;42:305-310.

32. Herzog AG, Schachter SC. Valproate and the polycystic ovarian syndrome: final thoughts. Epilepsia 2001;42:311-315.

33. Duncan S, Mercho S, Lopes-Cendes I, et al. Repeated neural tube defects and valproate monotherapy suggest a pharmacogenetic abnormality. Epilepsia 2001;42:750-753.

34. Rho JM, Donevan SD, Rogawski MA. Mechanism of action of the anticonvulsant felbamate: opposing effects on N-methyl-D-aspartate and gamma-aminobutyric acid A receptors. Ann Neurol 1994; 35:229-234.

35. The Felbamate Study Group in Lennox-Gastaut Syndrome. Efficacy of felbamate in childhood epileptic encephalopathy (LennoxGastaut Syndrome). N Engl J Med 1993;328:29-33.

36. Ketter TA, Malow BA, Flamini R, et al. Felbamate monotherapy has stimulant-like effects in patients with epilepsy. Epilepsy Res 1996;23:129-137.

37. Pellock JM, Brodie MJ. Felbamate: 1997 update. Epilepsia 1997; 38:1261-1264.

38. Carrazana EJ, Wheeler SD. Exacerbation of juvenile myoclonic epilepsy with lamotrigine. Neurology 2001;56:1424-1425.

39. Guerrini R, Dravet C, Genton P, Belmonte A, Kaminska A, Dulac O. Lamotrigine and seizure aggravation in severe myoclonic epilepsy. Epilepsia 1998;39:508-512.

40. Kanner AM, Frey M. Adding valproate to lamotrigine: a study of their pharmacokinetic interaction. Neurology 2000;55:588-591.

41. Faught E, Morris G, Jacobson M, et al. Adding lamotrigine to valproate: incidence of rash and other adverse effects. Postmarketing Antiepileptic Drug Survey (PADS) Group. Epilepsia 1999;40: $1135-1140$. 
42. Guberman AH, Besag FM, Brodie MJ, et al. Lamotrigine-associated rash: risk/benefit considerations in adults and children. Epilepsia 1999;40:985-991.

43. Tran TA, Leppik IE, Blesi K, Sathanandan ST, Remmel R. Lamotrigine clearance during pregnancy. Neurology 2002;59:251-255.

44. Marson AG, Hutton JL, Leach JP, et al. Levetiracetam, oxcarbazepine, remacemide and zonisamide for drug resistant localizationrelated epilepsy: a systematic review. Epilepsy Res 2001;46:259270.

45. Harden C. Safety profile of levetiracetam. Epilepsia 2001;42:3639.

46. Ragueneau-Majlessi I, Levy RH, Janik F. Levetiracetam does not alter the pharmacokinetics of an oral contraceptive in healthy women. Epilepsia 2002;43:697-702.

47. Radtke RA. Pharmacokinetics of levetiracetam. Epilepsia 2001;42: 24-27.

48. Patsalos PN. Pharmacokinetic profile of levetiracetam: toward ideal characteristics. Pharmacol Ther 2000;85:77-85.

49. Shorvon S. Oxcarbazepine: a review. Seizure 2000;9:75-79.

50. Schmidt D, Sachdeo R. Oxcarbazepine for treatment of partial epilepsy: a review and recommendations for clinical use. Epilepsy Behav 2000;1:396-405.

51. Lauria-Horner BA, Pohl RB. Pregabalin: a new anxiolytic. Expert Opin Investig Drugs 2003;12:663-672.

52. French JA, Kugler AR, Robbins JL, Knapp LE, Garofalo EA. Dose-response trial of pregabalin adjunctive therapy in patients with partial seizures. Neurology 2003;60:1631-1637.

53. Schachter SC. A review of the antiepileptic drug tiagabine. Clin Neuropharmacol 1999;22:312-317.

54. Kellinghaus C, Dziewas R, Ludemann P. Tiagabine-related nonconvulsive status epilepticus in partial epilepsy: three case reports and a review of the literature. Seizure 2002;11:243-249.

55. Schachter SC. Pharmacology and clinical experience with tiagabine. Expert Opin Pharmacother 2001;2:179-187.

56. Leppik IE, Gram L, Deaton R, Sommerville KW. Safety of tiagabine: summary of 53 trials. Epilepsy Res 1999;33:235-246.

57. Lau AH, Gustavson LE, Sperelakis R, et al. Pharmacokinetics and safety of tiagabine in subjects with various degrees of hepatic function. Epilepsia 1997;38:445-451.

58. Mula M, Trimble MR, Thompson P, Sander JW. Topiramate and word-finding difficulties in patients with epilepsy. Neurology 2003;60:1104-1107.

59. Lee S, Sziklas V, Andermann F, et al. The effects of adjunctive topiramate on cognitive function in patients with epilepsy. Epilepsia 2003;44:339-347.

60. Cerminara C, Seri S, Bombardieri R, Pinci M, Curatolo P. Hypohidrosis during topiramate treatment: a rare and reversible side effect. Pediatr Neurol 2006;34:392-394.

61. Johannessen SI. Pharmacokinetics and interaction profile of topiramate: review and comparison with other newer antiepileptic drugs. Epilepsia 1997;38(suppl 1):S18-S23.
62. Kyllerman M, Ben-Menachem E. Zonisamide for progressive myoclonus epilepsy: long-term observations in seven patients. Epilepsy Res 1998;29:109-114.

63. Kubota M, Nishi-Nagase M, Sakakihara Y, et al. Zonisamideinduced urinary lithiasis in patients with intractable epilepsy. Brain Dev 2000;22:230-233.

64. Knudsen JF, Thambi LR, Kapcala LP, Racoosin JA. Oligohydrosis and fever in pediatric patients treated with zonisamide. Pediatr Neurol 2003;28:184-189.

65. Shinoda M, Akita M, Hasegawa M, Hasegawa T, Nabeshima T. The necessity of adjusting the dosage of zonisamide when coadministered with other anti-epileptic drugs. Biol Pharm Bull 1996; 19:1090-1092.

66. French JA, Kanner AM, Bautista J, et al. Efficacy and tolerability of the new antiepileptic drugs II: treatment of refractory epilepsy: report of the Therapeutics and Technology Assessment Subcommittee and Quality Standards Subcommittee of the American Academy of Neurology and the American Epilepsy Society. Neurology 2004;62:1261-1273.

67. French JA, Kanner AM, Bautista J, et al. Efficacy and tolerability of the new antiepileptic drugs I: treatment of new onset epilepsy: report of the Therapeutics and Technology Assessment Subcommittee and Quality Standards Subcommittee of the American Academy of Neurology and the American Epilepsy Society. Neurology 2004;62:1252-1260.

68. Hixson JD, French JA. Guidelines for new antiepileptic drug evaluation. Rev Neurol Dis 2004;1(suppl 1):S18-S26.

69. Karceski S, Morrell MJ, Carpenter D. Treatment of epilepsy in adults: expert opinion, 2005. Epilepsy Behav 2005; 7(suppl 1):S1S64; quiz S65-S67.

70. Kwan P, Brodie MJ. Early identification of refractory epilepsy. N Engl J Med 2000;342:314-319.

71. Lhatoo SD, Wong IC, Polizzi G, Sander JW. Long-term retention rates of lamotrigine, gabapentin, and topiramate in chronic epilepsy. Epilepsia 2000;41:1592-1596.

72. Eadie MJ. Can anticonvulsant drug therapy 'cure' epilepsy? CNS Drugs 2001;15:679-690.

73. Berg AT, Shinnar S. Relapse following discontinuation of antiepileptic drugs: a meta-analysis. Neurology 1994;44:601-608.

74. Shinnar S, Berg AT. Does antiepileptic drug therapy prevent the development of "chronic" epilepsy? Epilepsia 1996;37:701-708.

75. Temkin NR. Antiepileptogenesis and seizure prevention trials with antiepileptic drugs: meta-analysis of controlled trials. Epilepsia 2001;42:515-524.

76. Rogawski MA. Diverse mechanisms of antiepileptic drugs in the development pipeline. Epilepsy Res 2006;69:273-294.

77. Bialer M. New antiepileptic drugs that are second generation to existing antiepileptic drugs. Exp Opin Investig Drugs 2006;15: 637-647.

78. Schmidt D, Rogawski MA. New strategies for the identification of drugs to prevent the development or progression of epilepsy. Epilepsy Res 2002;50:71-78. 